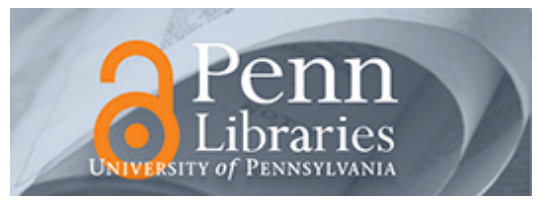

University of Pennsylvania

ScholarlyCommons

1999

\title{
The Trial of Cn. Piso in Tacitus' Annals and the "Senatus \\ Consultum de Cn. Pisone Patre": New Light on Narrative Technique
}

Cynthia Damon

University of Pennsylvania, cdamon@sas.upenn.edu

Follow this and additional works at: https://repository.upenn.edu/classics_papers

Part of the Classics Commons

\section{Recommended Citation}

Damon, C. (1999). The Trial of Cn. Piso in Tacitus' Annals and the "Senatus Consultum de Cn. Pisone Patre": New Light on Narrative Technique. The American Journal of Philology, 120 (1), 143-162. Retrieved from https://repository.upenn.edu/classics_papers/50

This paper is posted at ScholarlyCommons. https://repository.upenn.edu/classics_papers/50

For more information, please contact repository@pobox.upenn.edu. 
The Trial of Cn. Piso in Tacitus' Annals and the "Senatus Consultum de Cn.

Pisone Patre": New Light on Narrative Technique

\section{Disciplines}

Arts and Humanities | Classics 


\title{
THE TRIAL OF CN. PISO \\ IN TACITUS' $A N N A L S$ AND THE \\ SENATUS CONSULTUM DE CN. PISONE PATRE: \\ NEW LIGHT ON NARRATIVE TECHNIQUE
}

\author{
CYNTHIA DAMON
}

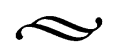

IN WRITING THE NARRATIVE of Germanicus' death and Piso's trial in Annals 2 and 3 Tacitus produced, in the estimation of two distinguished and perceptive Taciteans, "a text of unresolved ambiguity." For Woodman and Martin, Tacitus' achievement is the more striking when contrasted with the "monotonous confidence" of the Senate's resolutions in the aftermath of the trial, now available in the recently published Senatus Consultum de Cn. Pisone Patre. ${ }^{1}$ Woodman and Martin worked with this document even before its publication and use it to good effect in their commentary. The present essay treats a subject not easily addressed in the commentary format and beyond the purview of the document's first (1996) editors, namely, Tacitus' narrative technique.

For his history of this episode Tacitus uses the common and effective narrative structure in which a scene is replayed, sometimes called a mirror story: Piso's trial in Annals 3 contains the second telling of part of a story presented more fully in book 2, the story of Piso's eastern command and the death of Germanicus. Mirror stories are found in all ancient narrative genres and accomplish a variety of narrative tasks; here the structure conveys the historian's verdict on the trial. With the $S C P P$ now available we can see with unusual precision how Tacitus selects, suppresses, and deploys material in order to present his case. I argue that in book 2 he offers an account of what really happened (as he reconstructs it, anyway), then in book 3 shows how this "truth" was obscured by a haze of rumor and suspicion in a world driven by obsequiousness and dissimulation.

${ }^{1}$ Woodman and Martin 1996, 196 and 117. On the discovery and first publication of the $S C P P$ (Eck et al. 1996, in German; also a Spanish edition) see the Introduction to this special issue.

American Journal of Philology 120 (1999) 143-162 (c) 1999 by The Johns Hopkins University Press 


\section{MIRROR STORIES}

Mirror stories, like so much else in ancient historical writing, go back to the Homeric epics. In the Iliad and the Odyssey most mirror stories occur in direct speech: a character will repeat material already reported by the narrator, adapting it to his or her emotional state and rhetorical purpose. $^{2}$ Thus Thetis, for example, giving Hephaestus an account of the events that caused the loss of Achilles' armor, "simplifies" the story given in the narrative so as to heighten her son's role and strengthen the case for her own request (Il. 18.444-56). ${ }^{3}$ The structure serves to distinguish among the epic's various narrative levels, particularly between narrator-narrative and character-narrative.

In novels mirror stories are no longer confined to direct speech. A single example will illustrate how the structure's mechanics developed. One of several mirror stories in Apuleius' Metamorphoses is Lucius' trial for the murder of what he had taken to be a band of robbers (2.32-3.6). The trial culminates in a display of the victims: the cloth covering their bodies is swept away, only to reveal, not bloody corpses but wineskins that had been punctured by Lucius' sword and stained red by their contents. There were no real victims and Lucius was not guilty of murder; the trial was in fact a farce devised in honor of the god Risus, whose annual festival was being celebrated that day. The spectators at the trial knew what was going on the whole time, but the stranger Lucius did not. Nor (and this is the important point) did Apuleius' readers, for the fight scene was focalized through Lucius' eyes. The trial becomes a dramatic revelation of Lucius' vain and drunken misperceptions: the opponents in what Lucius saw as a heroic action were only some wineskins that had been left lying outside his host's door. By telling the story twice, once through Lucius' eyes, and once in the glare of a public trial, Apuleius re-enacts Lucius' discovery of his own clouded vision for the reader. Of course Lucius is the narrator of the Metamorphoses and knows perfectly well when he tells the story of the "battle" what was really going on, but he allows the reader to have the same eye-opening experience that he himself had had. And in fact Lucius' eyes are still only half open, as the event is described once more at 3.16-18, where Photis explains that the wineskins had been brought to

${ }^{2}$ De Jong 1985, 5 .

${ }^{3}$ De Jong 1987, 216-18. 
life by her mistress' magic (cf. 3.14, facti . . causam delitescentem nudari gestiens). Here each telling provides greater clarity about what actually occurred, the factum, and does so by adding new information. ${ }^{4}$

The mirror story is a structure that highlights the narrator's role in and authority over the narrative. The omniscient, infallible narrator of Homeric epic and drink-dazzled Lucius represent authoritative extremes. The historian, professing a commitment to the truth but only imperfectly in control of that truth, falls somewhere between them.

The narrative-plus-trial format of the Metamorphoses episode is particularly relevant to the Annals passages that are the focus of this essay. Trials are a recurrent feature of historical narrative (indeed Apuleius' story may parody history), but historians rarely risk their auctoritas on narrative strategies that mislead readers. Rather, they tend to use this kind of mirror story structure to convey a judgment on the trial itself. The infamous trial of the generals who won the sea battle at Arginusae but failed to rescue their own shipwrecked survivors, for example, becomes infamous in Xenophon's account in part because the arguments that result in the execution of six generals are flatly contradicted by Xenophon's narrative of the battle (Hell. 1.7, trial; 1.6.29-35, battle).$^{5}$ Of course Xenophon does not say that the trial was infamous (though he does note, at 1.7.35, that the Athenians later repented of their actions); he simply juxtaposes the two accounts. Livy tends to give his readers more guidance. When Scipio Africanus was charged with having taken money from Antiochus (38.51.1-2), for example, the reader has already encountered a narrative of the negotiations between Africanus and Antiochus' agents in which there was nothing that would support that charge (37.34-36). There Livy gave Scipio a speech in which Scipio quite explicitly turned down a bribe and refused to use his son as a bargaining chip in affairs that concerned the res publica

${ }^{4} \mathrm{C}$. P. Jones, through his response to an earlier version of this essay at a meeting of the New England Ancient Historians Colloquium, improved the discussion of this passage. Another Apuleian narrative describing both events resulting in a trial and the trial itself is found at Met. 10.2-12. Here again the trial narrative introduces new material into the tale: we learn that, thanks to the doctor's suspicions, the "poison" he had sold to the evil step-mother had not killed the youth but only put him into a deep sleep.

sI owe this reference to the Journal's editor, P. Stadter. E. Badian cites the trial of the Plataeans at Thuc. 3.52-68 as a comparable case (one with the interesting difference that some of the ground-laying narrative comes from Herodotus, not Thucydides himself: compare, e.g., 3.55.1 with Hdt. 6.108); see further note 8 below. Examples could be multiplied. 
(37.36.1-7). That speech looks very much like a preemptive response to the charges Livy knew were coming. As the story unfolds for the reader, however, the first telling grounds the second. In the trial narrative Livy steers the reader firmly by characterizing the charges as "based in suspicion rather than evidence" (suspicionibus magis quam argumentis, 38.51.1): not even the suspicions (let alone the charges) had any basis in the narrative, so the prosecutors appear purely malicious. A further authorial dictum reinforces the point: "No mud could be made to stick [on Scipio], so they attacked with what they could, namely jealousy" (infamia intactum [Scipionem] invidia, qua possunt, urgent, 38.51.4). In fact, Livy treats the trial of Scipio as a political battle fought out in the judicial arena, most improperly; he has nothing but scorn for the men who presumed to call Rome's greatest living general into court. The tone of remarks such as suspicionibus magis quam argumentis and invidia, qua possunt, urgent relies on the discrepancy between the charges made by the prosecutors and Livy's own account of what had happened. In effect, the historian's narrative of events justifies his condemnation of the accusation. Tacitus devotes a much larger proportion of his narrative to trials than does Livy or indeed any extant earlier historian. Piso's trial deserves particular scrutiny because we can now go beyond the analysis of narrative effect here and see something of how Tacitus transforms materiel into historical narrative.

\section{CLARIFICATION}

Tacitus' narrative of Piso's governorship of Syria from his appointment by Tiberius in 17 C.E. to his final forced departure at the end of 19 occupies some eighteen chapters of Annals 2 (2.43, 55, 57-58, 68-81). The outline of the story is well known: numerous clashes between Piso and Tiberius' heir-apparent, Germanicus, Piso's withdrawal from Syria, Germanicus' death, armed conflict between soldiers loyal to Piso and those loyal to the authority of Germanicus, Piso's defeat, and finally the summons to Rome. The trial in Rome occupies chapters 10-19 of book 3 , another generous allotment of space: no other trial receives more than about three chapters, and most are much shorter than that. Here the events of Piso's command are variously replayed in Tiberius' opening speech (3.12), in the summaries of the cases of prosecution and defense (3.13-14.2), and in Piso's letter to Tiberius (3.16.3-4). Discrepancies among Tacitus' multiple tellings of the story of Piso and Ger- 
manicus contribute materially to his characterization of the period, a characterization that the $S C P P$ now allows us to understand more fully. To be sure, the SCPP does not report the whole truth about events-it is no less carefully crafted than Tacitus' own narrative-but it can, I think, be taken to be the truth about what the Senate on 10 December in 20 C.E. believed an acceptable response to the questions with which Tiberius had framed their verdict on Piso and his associates and an acceptable obeisance to the new constellation of powers at court. ${ }^{6}$ The three discrepancies discussed below, a small sample of the available material, include both differences and silences. I look first at Tacitus' versions of an incident, then turn to the Senate's report. ${ }^{7}$

To begin with some general points, however, it is clear from their relative lengths that Tacitus' narrative of events (eighteen chapters) will be more detailed than the narrative of the trial (ten chapters, and of these only a portion is devoted to events that occurred in the East). (In what follows I refer to the listed chapters from book 2 as "the narrative" and those of book 3 as "the trial," shorthand, respectively, for "the narrative of events" and "the narrative of the trial.") Matters that appear in the narrative but not at the trial will thus not necessarily be significant, while matters pertaining to the East that are brought up at the trial but not in the narrative ought to repay inspection. ${ }^{8}$

It is also clear that Tacitus knows more about the trial than is reported in the SCPP: he knows the identity of the prosecutors, for example, and is aware of the charges advanced by Fulcinius Trio, even if he dismisses them as inania and vetera (3.13.1). The 1996 editors of the $S C P P$ argue that Tacitus drew on the senatorial acta for his account, on

${ }^{6}$ For Tiberius' questions see SCPP lines 6-11.

${ }^{7}$ It is not my intention here to give a complete account of the differences between Tacitus' narratives and the SCPP but simply to examine the passages of the SCPP that are relevant to material suggested by the mirror story format.

${ }^{8}$ This fairly crude triage only serves to identify a category of potentially interesting discrepancies; each such item needs further individual evaluation. The intended contrast is with a discrepancy such as that at Thuc. 3.54.5, where the Plataean defendants claim to have rendered Sparta aid in connection with the helot revolt, whereas Thucydides in the narrative has specified only Athenian assistance (1.101-3). That narrative, however, comes in the explicitly summary Pentecontaetia; the Plataeans are presumably among the "other allies" twice mentioned $(1.102 .1,3)$. A potentially significant discrepancy in the same trial is the Plataean assertion that the Thebans attacked on the day of a festival (3.56.2), something Thucydides does not mention during his detailed narrative of the attack (2.2-4). For discussion of the significance see Gomme 1956 ad loc. and Hornblower 1991 ad loc. 
the grounds that he (and he alone) ${ }^{9}$ offers material favorable to Piso, which was only likely to have been preserved in the Senate's records. ${ }^{10}$ Woodman and Martin are rather more cautious (1996, 114-17). Certainty still seems impossible, but it does seem safe to say that if Tacitus omits a detail that is found even in the SCPP, he did so not because he was ignorant of it, but because he did not want it. ${ }^{11}$ We will see a noteworthy omission below.

As a first example of an item that appears in Tacitus' trial narrative but not in the narrative of events consider the phrase auctore senatu in Tiberius' trial-opening speech. At the time of Piso's appointment, Syria was a province with a strong military garrison commanded by an imperial legate. Yet Tiberius claims that he appointed Piso to the post after consulting the Senate (adiutorem ... Germanico datum a se auctore senatu rebus apud orientem administrandis, 3.12.1). In the narrative, however, though Germanicus' command had been conferred decreto patrum, Piso's had not:

tunc decreto patrum permissae Germanico provinciae, quae mari dividuntur ... sed Tiberius demoverat Syria Creticum Silanum, per adfinitatem conexum Germanico ... praefeceratque Cn. Pisonem. ${ }^{12}$

The overseas provinces were assigned to Germanicus by decree of the Senate ... but Tiberius had removed Creticus Silanus (who was closely connected with Germanicus) from Syria and put $\mathrm{Cn}$. Piso in charge of the province.

${ }^{9}$ The parallel tradition presents Piso as a villain: Suet. Cal. 2, obiit [Germanicus]... fraude Tiberi, ministerio et opera Cn. Pisonis; cf. Tib. 52.3, etiam causa mortis fuisse ei [Ger-

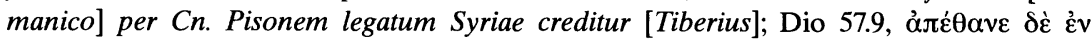

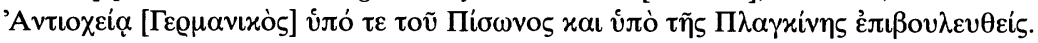

${ }^{10}$ See, e.g., Eck et al. 1996, 140 n. 353, 191, 216, 245 n. 80; the proposition is defended at 295-96. For recent general discussions see Goodyear 1981 ad 1.81 .1 (in ipsius orationibus) and Martin and Woodman 1989 ad 4.8 .2 (oratione continua), the latter with bibliography. It is of course possible that the records were used by Tacitus' literary source, not by Tacitus himself. And also that the double narrative structure was inherited by him from a literary source. But to avoid positing a Tacitus before Tacitus I refer the compositional strategies that I discuss here to the consul of 97. In support of this is the fact that the other surviving witnesses of the "common source" show very little interest in Piso (see note above).

${ }^{11}$ On Tacitus' use of documentary sources see Talbert, this issue.

${ }^{12}$ Translations are my own. 
According to this narrative, Tiberius, and Tiberius alone, put Piso in charge of Syria. He did so, moreover, before Germanicus' mission was defined (demoverat, praefecerat). Tacitus also reinforces the reader's sense of Tiberius' personal responsibility for this decision by suggesting that it was Piso's difficult personality and scorn for Germanicus that led Tiberius to appoint him to Syria:

ingenio violentum et obsequii ignarum. ... vix Tiberio concedere, liberos eius ut multum infra despectare.

Piso was rash by nature and did not know how to take his cue from others. ... He hardly deferred to Tiberius and considered Tiberius' children far beneath him.

This description stands in parallel to the notice of Creticus Silanus' too-close connection with Germanicus, which, according to Tacitus, led Tiberius to remove him from the post. Neither Piso's insita ferocia (2.43.2) nor Creticus' relationship to Germanicus is likely to have been aired at a Senate meeting as a criterion for appointment or dismissal; such considerations suggest rather a princeps' private deliberations. ${ }^{13}$

One may compare an appointment made just two years later. In the hope of restoring peace to a restive Thrace, Tiberius chose a governor for neighboring Moesia with careful attention to relations with the Thracian king Rhescuporis:

defuncto $\mathrm{Pa}\langle\mathrm{n}\rangle$ dusa, quem sibi infensum Rhescuporis arguebat, Pomponium Flaccum, veterem stipendiis et arta cum rege amicitia eoque accommodatiorem ad fallendum, ob id maxime Moesiae praefecit.

At the death of Pandusa [the former governor of Moesia], whom Rhescuporis had accused of hostility to himself, he put in charge of Moesia Pomponius Flaccus, who was a seasoned veteran and a close friend of the king and therefore more suitable for a deception.

According to these narratives, the Senate plays no part in this appointment or in that of Piso. And such would seem to have been Tiberius' normal practice with ordinary appointments, for in Suetonius' list of all the small matters on which Tiberius, to his credit, consulted the Senline 27).

${ }^{13}$ Piso's ferocitas morum was, however, noted by the Senate after the fact (SCPP 
ate, only "extensions of commands and major campaigns" (ad patres conscriptos referretur... quibus imperium prorogari aut extraordinaria bella mandari ... placeret, Tib. 30) are mentioned on the subject of appointments. Since consultation was apparently not the norm and since it is not evidenced in the foregoing narrative, auctore senatu at 3.12.1 serves to characterize Tiberius. ${ }^{14}$ That is, Tacitus' Tiberius appears to be trying to share out the blame that belonged to him alone.

In the $S C P P$ the Senate is not at all eager to accept responsibility, even partial, for Piso's appointment. It agrees with Tacitus' narrative about their role in designing Germanicus' command, and agrees, too, with the description of Piso's role as that of adiutor (adiutorem se [Pisonem] datum esse Germanico Caesari, qui a principe nostro ex auctoritate huius ordinis ad rerum transmarinarum statum componendum missus esset, lines 29-31). ${ }^{15}$ However, the picture becomes more obscure with the description of Piso as "attached to a proconsul and indeed to a proconsul about whom a law had been carried in a public assembly providing that in whatever province he entered he had greater imperium than the province's proconsular governor" (33-35). A senatus consultum presumably lay the groundwork for the lex, but it is not clear from the phrasing here whether that lex (and by extension the original senatus consultum) was responsible for Piso's adlection. ${ }^{16}$ Adlectus pro consule is in fact a difficult phrase. Eck is probably correct in taking pro cos as a dative (1996, $40 \mathrm{n} .41)$, but adlectus is difficult to parallel and seems a strange designation for the legatus Augusti pro praetore in Syria. ${ }^{17}$ Furthermore, as Eck notes (1996, 161), Germanicus' authority over Piso is not covered by the phrase "greater imperium than the province's proconsular governor" (maius ... imperium quam ei, qui eam provinciam $\operatorname{proco}(n) s($ ule $)$ optineret, lines 34-35), since as Tiberius' legate in Syria

${ }^{14}$ See above on mirror stories in speeches as a technique of characterization.

${ }^{15}$ Adiutor is a peculiar designation for an imperial legate, as is sufficiently shown by comparison with the adiutores cited in Eck et al. 1996, 157-58, and Woodman and Martin 1996, 141.

${ }^{16}$ For the mechanics see Talbert 1984, 433-35. See also Eck et al. 1996, 157, maintaining that the phrase auctore senatu may have had a documentary source, presumably the senatus consultum or the lex itself. For further discussion see Woodman and Martin 1996 ad loc.

${ }^{17}$ For adlectus + dative cf. CIL V 5036.7, adlecto annon(ae) leg. III Italic(ae). For other military secondings see TLL s.v., 1665.74-82. For Piso's post cf. Tac. Ann. 2.43.1, praefecerat; 3.12.2, legatus; Suet. Cal. 2, Syriae praepositus; Suet. Tib. 52.3, legatus Syriae. 
Piso did not have proconsular imperium. Contrast Tacitus' formula, which specifies Germanicus' authority in both senatorial and imperial provinces: "the provinces beyond the sea were given to Germanicus and likewise, wherever he went, imperium superior to that of governors appointed by lot or sent by the princeps" (permissae Germanico provinciae, quae mari dividuntur, maiusque imperium, quoquo adisset, quam iis qui sorte aut missu principis obtinerent, 2.43.1). Germanicus' authority over Piso must lie in the term adlectus, but it is precisely here that the responsibility for Piso's appointment is left unstated: Who did the "attaching"?

Tacitus' narrative, then, clarifies matters that the $S C P P$ leaves quite inexplicit: who appointed Piso (Tiberius), what his official position was (legate in Syria), and how his authority measured up to that of Germanicus (lesser). Whether Tacitus' clarifications are correct is another matter. It is certainly possible, perhaps even probable, that auctore senatu at 3.12.1 is historically correct, but it is also important to realize that, measured against Tacitus' narrative of events, it seems unfounded. Not only that, but if adlectus is interpreted correctly above (that is, if Piso's position was redefined by the lex about Germanicus' imperium), it would seem that Tacitus, in expressing their relative positions only in general terms (maius... imperium, quoquo adisset, quam iis qui sorte aut missu principis obtinerent), omits information that would have made his account of Piso's intransigence almost incredible and certainly indefensible. (For Tacitus' defense of it, see below.)

\section{SUPPRESSION}

A clearer case of suppressed evidence can be seen in the discrepant versions of Piso's attempt to secure the affection of his troops in Syria. In the narrative, Tacitus lists the unusual measures with which Piso attempted to win over his soldiers:

postquam Syriam ac legiones attigit, largitione, ambitu, infimos manipularium iuvando, cum veteres centuriones, severos tribunos demoveret locaque eorum clientibus suis vel deterrimo cuique attribueret, desidiam in castris, licentiam in urbibus, vagum ac lascivientem per agros militem sineret, eo usque corruptionis provectus est, ut sermone vulgi parens legionum haberetur.

On reaching the army in Syria Piso began to distribute gifts to his troops, to bribe them, to help even the humblest soldiers. Senior centurions and 
strict tribunes he replaced with his own hangers-on and with men of utterly bad character. He tolerated slackness in camp, disorderly conduct in town, and let the soldiers misbehave at will throughout the territory. $\mathrm{He}$ had gone so far in corrupting them that in the talk of the common soldier he was called "father of his legions."

What Piso intended to achieve by cultivating the affections of his troops in this way is not stated here, but earlier Tacitus had ascribed to Piso an interpretation of his mission in Syria that is fully consonant with these actions: he had been sent, as he saw it, as a brake on Germanicus (ad spes Germanici coercendas, 2.43.4). ${ }^{18}$ And this interpretation of Piso's purpose is the one that makes sense of his behavior (and that of Plancina) for the soldiers, who assume that the two are doing Tiberius' bidding (haud invito imperatore ea fieri occultus rumor incedebat, 2.55.6). Thus the narrative.

In the trial account we find the charge of corrupting the troops first in Tiberius' opening speech. The judges were to decide:

illud reputate, turbide et seditiose tractaverit exercitus Piso, quaesita sint per ambitionem studia militum, armis repetita provincia, an falsa haec in maius vulgaverint accusatores.

whether Piso's management of the army was disruptive and seditious, whether he procured the goodwill of his soldiers to promote his own cause and reentered his province by force of arms, or whether the charges are fabricated or exaggerated.

Commentators have noted that Tacitus' Tiberius uses milder language than that of the narrative ("procured the goodwill of his soldiers" instead of "corrupting them"), but the way he frames the questions for the Senate is not evidence of his fair-mindedness but rather a strategy of dissociation. The question Tiberius asks is not "Did Piso procure the goodwill of his soldiers?" but "Did Piso procure the goodwill of the soldiers to promote his own cause?" Per ambitionem assigns responsibility to Piso alone and implicitly contradicts the occultus rumor about Tiberius' backing.

${ }^{18}$ Piso may well have mistaken Tiberius' intent, but that is a separate question. Tacitus leaves the question of data . . a Tiberio occulta mandata quite murky (2.43.4, with Goodyear 1981 ad loc.; see also 3.16.1 on Piso's libellus and Woodman and Martin 1996 on 3.14.3 †scripsissent expostulantes $\dagger$ ). 
When the charge comes up again in the prosecution case, a different tactic is in play. According to the accusers, Piso "corrupted the troops" and did so out of "hatred of Germanicus and a desire for revolution" (obiecere odio Germanici et rerum novarum studio Pisonem vulgus militum per licentiam et sociorum iniurias eo usque conrupisse, ut parens legionum a deterrimis appellaretur, 3.13.2). Stronger language"corruption" instead of "procuring the affection" and "desire for revolution," instead of "to promote his own cause"-and differently deployed. Studium rerum novarum is now paired with a second motive, namely, odium Germanici, for the prosecution is eager to link the two charges-treatment of Germanicus and sedition-that Tiberius had carefully distinguished (3.12.2-3). But the motives assigned by the prosecution are as specific to Piso as Tiberius' per ambitionem. And even the defense accedes to this view, indeed to the very term Tiberius had used: in their estimate, "Piso's military ambition could not be denied" (neque militarem ambitionem . . infitiari poterat, 3.14.1). The "defense" that Tacitus had provided for Piso in the narrative-opposition to Germanicus as a mission from Tiberius-could not be used at the trial.

In the narrative, then, Piso indulges his troops to strengthen his position against Germanicus, while at the trial both prosecution and defense defer to Tiberius' self-interested view that Piso was not resisting Germanicus but promoting his own cause. A glance at the SCPP will show that the differences between these accounts are not simply evidence of Tacitus' skillful prosopopoeia.

In the $S C P P$ the Senate adduces corruption of the troops among the (numerous) items that support its verdict that Piso deserved a harsher punishment than the one he had brought on himself by suicide. ${ }^{19}$ The Senate's version of the charge agrees with Tacitus' trial versions in assigning the motivation for Piso's actions to Piso alone, though here (line 50) the relevant trait is crudelitas, not ambitio. Not only is there no hint of Tacitus' narrative version, which suggested that Piso believed himself to be acting in Tiberius' interest, but there is even evidence against it. The Senate expands the phrase militarem discipulinam corrupisset with three instrumental gerunds: Piso corrupted discipline

${ }^{19}$ Arbitrari senatum non optulisse eum se debitae poenae, sed maiori et quam inminere sibi ab pietate et severitate iudicantium intellegeba\{n\}t subtraxisse (lines 71-73). See Eck et al. 1996, 192, on the moral rather than juridical character of this verdict. 
non solum indulgendo militibus, $\langle$ e $\rangle$ his, qui ipsis praesunt, more vetustissumo parerent, sed etiam donativa suo nomine ex fisco principis nostri dando, quo facto milites alios Pisonianos, alios Caesarianos dici laetatus sit, honorando etiam eos, qui post talis nominis usurpationem ipsi paruissent.

(lines 53-57)

not only by indulging the soldiers, 〈so that they would not obey their superiors in accordance with our most venerable tradition, but also by giving donatives in his own name from the fiscus of our princeps, after which he took pleasure that some soldiers were called "Piso's men" and others "Caesar's men," and also by honoring those who, after adopting such a name, had obeyed himself.

Taking personal credit for donatives that Tiberius paid for and allowing, indeed enjoying, the public expression of allegiance to himself implied by the name Pisoniani is behavior that accords much better with Tiberius' per ambitionem than with the narrative's ad spes Germanici coercendas. No donative is mentioned by Tacitus, and he expresses the troops' enthusiasm for Piso not with the name Pisoniani but with the phrase parens legionum, which avoids reference to partisan divisions within the army of Syria. ${ }^{20}$

Let us take stock, beginning, as best we can, with what happened. Piso paid his troops donatives in his own name, and some soldiers in the Syrian legions began to identify themselves as "Piso's men," Pisoniani. (It seems reasonable to assume that the Senate had heard testimony justifying their statement; cf. testes cuiusque ordinis auditi, line 25.) Whether these events are to be connected with the first phase of Piso's operation in Syria or with the period of his civil war is unclear; both phases are mingled in the charges mustered in this portion of the inscription (lines 29-70). We do not know, either, how the actual prosecution and defense dealt with the evidence of corruption, though we have seen that the Senate, at least, interpreted it in a way that would be acceptable to Tiberius, viewing Piso as a self-motivating rebel. But in the Annals, while the trial follows this explanation of Piso's treatment of his

${ }^{20}$ The phrase parens legionum is echoed in Piso's parainesis: consisterent in acie, non pugnaturis militibus, ubi Pisonem ab ipsis parentem quondam appellatum ... non invalidum vidissent (2.80.2). The importance of the imperial name is reiterated near the end of the $S C P P$, where the Senate urges the soldiers to accord the maximum auctoritas to officers qui fidelissuma pietate salutare huic urbi imperioq(ue) p(opuli) R(omani) nomen Caesarum coluissent (164-65). 
troops in showing both prosecution and defense acceding to Tiberius' convenient and connection-severing per ambitionem, the narrative that preceded it did not. And it appears that in order to write a different version into the narrative, that is, in order to present Piso as deeply loyal to Tiberius and acting in accordance with what he takes to be the wishes of that enigmatic ruler, Tacitus omits evidence that resists his reading of Piso's governorship.

The discrepancy between narrative and trial versions of Piso's corruption of the troops in Syria, then, illustrates not only Tacitus' familiar flair for finding by research or analysis the motives behind actions (Piso's loyalty, Tiberius' self-protection, senatorial sycophancy) and his deft hand at characterization thereby, but also the beginnings of a (negative) verdict on this particular trial: the full and fair investigation Tiberius seemed to be calling for in his trial-opening speech was neither wanted by him (since he took care to establish Piso's motive at the very outset of proceedings) nor possible in a Senate that would only follow his lead. The historian challenges Tiberius' per ambitionem by building a different analysis of motive into his narrative; from the $S C P P$ we can now see that he will give his analysis priority over evidence that conflicts with it.

\section{ADDING IT ALL UP}

The final discrepancy to be considered here concerns the question of Piso's responsibility for the death of Germanicus.

I begin with the narrative. In chapter 69 of book 2 of the Annals we find Germanicus on his deathbed. Germanicus was convinced that his illness-Tacitus calls it a morbus - was due to Piso's poison, but the historian is carefully noncommittal: we are in the realm of suspicion, not fact, and he does not vouch for Germanicus' persuasio. Instead he shows how the belief was created: evidence of magical attacks kept turning up, and Germanicus was told that Piso was sending spies.

saevam vim morbi augebat persuasio veneni a Pisone accepti; et reperiebantur solo ac parietibus erutae humanorum corporum reliquiae, carmina et devotiones et nomen Germanici plumbeis tabulis insculptum, semusti cineres ac tabo obliti aliaque malefica, quis creditur animas numinibus infernis sacrari. simul missi a Pisone incusabantur ut valetudinis adversa rimantes. 
His belief that he had been poisoned by Piso only made the illness afflict him more cruelly. And bits of human bodies kept turning up-they had been concealed in the walls and floor-as did magic spells, curses, and lead tablets with Germanicus' name cut into them. Also half-burnt cinders smeared with gore, and other malignant objects that looked like devices believed to consign souls to the powers of the underworld. And at the same time it was said that Piso's messengers had come spying, to see if Germanicus had a relapse.

Germanicus' friends share his belief in the poisoning, and on the occasion of his funeral they behave in such a way as to broadcast their suspicions, allowing the corpse to be exposed to public view so that any external signs of poisoning would be seen by all. But here again Tacitus inserts a note of caution: only those who were looking for evidence of poison found it, he says (2.73.4). Public opinion was only too eager to spread the report of poison, as when people likened Germanicus to Alexander the Great in respect (among other things) of his manner of death, both of them dying among foreigners but falling prey to the plots of their own friends (insidiis suorum, 2.73.2). ${ }^{21}$ The fact that a woman with a reputation as a poisoner and a close connection with Piso's wife was taken into custody gave the rumor-mongers something more to talk about, as did her sudden demise en route to Rome (infamis veneficiis and Plancinae percara, 2.74.2; demise, 3.7.2). In none of these passages does Tacitus vouch for poison. Indeed à propos of the arrest of the poisoner he protests that Germanicus' friends were behaving precipitously, "as if the case were already in court" (tamquam adversus receptos iam reos, 2.74.2).

More significantly, he never gives any details about how poison was administered. The absence of the poisoning from the narrative cannot be attributed to a lack of interest in such material, for Tacitus gives very precise information about the poisoning of Tiberius' other son, Drusus, whose death was eventually proven to be a murder (4.8.1; $\mathrm{cf}$. 4.11.1-3; cf. also the dinner-poisonings of L. Iunius Silanus, ab his [necis ministris] proconsuli venenum inter epulas datum est apertius quam ut fallerent, 13.1.2, and Britannicus, 13.15.5-16.2). As far as one can tell from the narrative, then, Piso did not poison Germanicus.

${ }^{21}$ Poison, the fatalis scyphus, was among the explanations offered for Alexander's early death (see, e.g., Sen. Ep. 83.23). For further discussion of Tacitus' use of this comparison see Paladini 1984. 
At the trial, the prosecution puts the poisoning charge front and center. Piso was supposed to have touched Germanicus' food with poison-smeared hands (in convivio Germanici, cum super eum Piso discumberet, infectos manibus eius cibos arguentes, 3.14.1). ${ }^{22}$ This, says Tacitus, seemed absurd: how would Piso have dared to do such a thing when Germanicus himself and plenty of other people, too, could see what was going on, not to mention Germanicus' slaves? (. . quippe absurdum videbatur inter aliena servitia et tot adstantium visu, ipso Germanico coram, id ausum? 3.14.2). Accordingly, Tacitus describes the defense as confident in its ability to reply to this charge and reports that Piso offered to let the court examine his own slaves and demanded that the alleged agents be put to torture (3.14.2).

So far there is a comfortable coherence between narrative and trial: we have been given no solid evidence of poisoning. And a glance at the $S C P P$, where there is not a word about poison, but only an echo of Germanicus' deathbed assertion that Piso was the cause of his death - the Senate judged that "the dying Germanicus (who himself declared the elder $\mathrm{Cn}$. Piso to have been the cause of his death) not without due cause renounced his friendship with him" (lines 27-29) - seems to add still more happy consensus. But the trial is not over.

The prosecution had accused Piso of killing Germanicus via both poison and magic, devotionibus et veneno (3.13.2). Tacitus' defense, which was so well prepared to face the charge of poison, has nothing to say about the magical attacks. And we saw in the narrative that curse tablets with Germanicus' name on them, human remains, and other evidence of destructive magic had turned up in Germanicus' house, repeatedly, in fact (reperiebantur, 2.69.3). By putting the devotiones in the narrative and not discrediting them at the trial Tacitus recreates for the reader the suspicions that survived for generations after the fact (Germanici morte, non modo apud illos homines qui tum agebant, etiam secutis temporibus vario rumore iactata, 3.19.2). Suspicions that, in Tacitus' view, the senators judging Piso acted on at the time: though there was

${ }^{22}$ It is in fact only thanks to the elder Pliny that we know that the prosecutor Vitellius brought up the signs of poisoning observed in the corpse of Germanicus: certe exstat oratio Vitelli, qua Gn〈a〉eum Pisonem eius sceleris coarguit, hoc usus argumento palamque testatus non potuisse ob venenum cor Germanici Caesaris cremari (NH 11.187). Cf. Suet. Cal. 1.2, Antiochiae obiit [Germanicus], non sine veneni suspicione. Nam praeter livores, qui toto corpore erant, et spumas, quae per os fluebant, cremati quoque cor inter ossa incorruptum repertum est, cuius ea natura existimatur, ut tinctum veneno igne confici nequeat. 
nothing to connect Piso with the magical apparatus, the Senate, convinced that somebody did something to Germanicus (numquam satis credito sine fraude Germanicum perisse, 3.14.3), held Piso responsible. His suicide only confirmed their belief in his guilt, a belief that underlies the numerous expressions of satisfaction at the successful avenging of Germanicus (3.18.2-3; see below). Xenophon and Livy reveal judicial injustice by writing the contrary evidence into the narrative; Tacitus accomplishes the same thing by leaving a gap. Not, as in Apuleius, a gap that misleads, but a gap that reveals all too much about the nature of the new principate.

There is a further significant discrepancy to be considered here, that between Tacitus' version and the official document, which was published throughout the empire "in order that the sequence of the entire transacted affair could more easily be handed down to the memory of future generations and they might know what the Senate had thought both about the exceptional restraint of Germanicus Caesar and about the crimes of the elder Cn. Piso" (lines 165-68). In the SCPP the Senate, in effect, disavows any interest in the cause of Germanicus' death. The scelera with which they charge Piso fall under the (broad) headings of insubordination and damaging the interests of the res publica, the latter by corrupting military discipline, by meddling in foreign affairs on his own account, and by engaging in a civil war (lines 23-70). And the Senate prefaces the report of its views with an expression of thanks to the immortal gods "because they did not permit the dastardly designs of $\mathrm{Cn}$. Piso the elder to upset the tranquillity of the present state of the republic" (quod nefaris consilis Cn. Pisonis patris tranquillitatem praesentis status $r(e i)$ p(ublicae)... turbari passi non sunt, 12-14). The inscription thus agrees with what Tacitus tells us about Tiberius' attitude to Piso, that he was implacable toward Piso because of the civil war ( $o b$ bellum provinciae inlatum, 3.14.3), but it does not fit with Tacitus' own account, where the death of Germanicus is a much more prominent issue than Piso's disturbance of the imperial peace: Piso's civil war, for example, is presented as hopeless from the start and negligible in its effect, and it is for the avenging of Germanicus that thanks are voted at 3.18 .3 (see below). ${ }^{23}$

${ }^{23}$ Piso's negligible civil war: his troops are hopeless: desertores, lixae, tirones, servitia, some cowardly auxilia sent by Cilician reguli; they cannot be said to comprise a legion, even if they are in numerum legionis. Even in his pre-battle speech the most Piso can say is that they are non invalidum (2.80.2). Their position, thanks to Piso's prudent general- 
The gap between Tacitus' version and the SCPP only widens with the conclusion of Tacitus' report of the trial. For in the end Tacitus gives authorial support to the widespread view that Piso's suicide avenged the death of Germanicus. Vengeance was what Germanicus' friends had sworn to obtain (2.71.5), vengeance was what Germanicus' widow intended to get when she returned to Rome with Germanicus' ashes and his children (2.75.1), vengeance was what the populace hoped the trial would provide (3.7.1). In the aftermath of the trial, moreover, the Senate of Tacitus' account devised tokens of vengeance accomplished: an "altar of vengeance" (ara ultionis) was proposed, and one ingratiating senator suggested a formal vote of thanks to the imperial family "because Germanicus had been avenged" ( $o b$ vindictam Germanici, 3.18.2-3). Tacitus tells us that Tiberius vetoed the ara, but he says nothing about what happened concerning the vote of thanks. There was in fact an official vote of thanks, but, as we have seen in the SCPP, the thanks went to the gods for the failure of Piso's civil war, not for the avenging of Germanicus.

It is all the more remarkable, then, that at the end of the story Tacitus adds his own voice to the chorus of characters who speak of vengeance. The final act in the avenging of Germanicus' death, according to Tacitus, was Tiberius' distribution of priesthoods as rewards for Piso's prosecutors: is finis fuit ulciscenda Germanici morte (3.19.2). Vengeance, of course, presumes guilt, and although Tacitus had said nothing conclusive about Piso's guilt on the charge of murder, in his final word he issues no reminder that the avenging of Germanicus might have been based on a mistaken premise. ${ }^{24}$ The details of what did hap-

ship, is a strong one, but they have no courage, no hope, not even any weapons worthy of the name. Sentius, on the other hand, has Romanae cohortes (2.80.4), a valida manus et proelio parata. Piso is quickly left with his back to the wall, pleading with his opponents, for the sedition he aroused brought him one adherent only from the very legion (presumably "corrupted") that Domitius Celer had considered maxime novis consiliis idonea (2.79.3). Where now are the troops who were ad mala obsequia prompti, ready to abet Plancina's contumeliae (2.55.6)? In the end, Piso's "civil war" is shown to have been persistence in a vain hope, pertinacia (2.81.3). But the fact that Piso's name was considered a possible substitute for that of L. Arruntius in Augustus' deathbed list of the capaces imperii (1.13.3) makes one wonder if there wasn't more to Piso's civil war than Tacitus allows.

${ }^{24}$ For this point see the perceptive remarks in Walker's discussion $(1952,121-26)$ of Piso's role in the story of Germanicus' death and the trial that followed it. Also, more recently, Develin 1983. 
pen (magical attacks, author unknown) and what could not possibly have happened (Piso laying poisoned hands on Germanicus' food) are in fact forgotten as the event is consigned to the past and Germanicus' death goes down as a murder that was duly avenged by Piso's suicide and the posthumous punishments imposed on his name and his family. ${ }^{25}$

In a sententia on the death of Germanicus' brother Drusus, Tacitus maintains that "rumors connected with the deaths of powerful men are always quite vicious" (atrociore semper fama erga dominantium exitus, 4.11.2). The statement is equally relevant to the death of Germanicus, and the vicious rumors in this case seem to have taken a particularly tenacious hold in the historical tradition on Tiberius' reign. Tacitus does not suppress them or argue them away (as he does in the case of some especially monstrous variants on the story of Drusus' death, for example) but uses the mirror story structure to give them their proper place in history. Book 2 provides a description of "what really happened" (carefully selected, as we have seen, to support Tacitus' explanation of Piso's character and motive: arrogant but fundamentally loyal to Tiberius, resisting Germanicus' efforts to the best of his ability and indecently pleased by his death, then foolish enough to attempt a hopeless civil war). Book 3 then offers a second account, one that shows how "what happened" was filtered through the trial to produce an entirely new version of history. This new version held that Germanicus had been killed, that Tiberius wanted to share out the blame for an appointment that had failed, that Piso's defenders could not defend him, and finally, that through the trial and suicide of Piso vengeance had been accomplished. ${ }^{26}$

The new inscription from Spain allows us to see an important element of Tacitus' historiographical practice, namely, his awareness of but deviation from the official record of events. Tacitus is a seductive writer, and although he concludes his account of Piso and Germanicus with a sober assessment of the difficulty of discovering the truth-"we are in the dark about even the most important events," he says, adeo maxima

${ }^{25}$ And his associates (see SCPP, lines $120-23$ ), but of these Tacitus says nothing at all.

${ }^{26}$ The process that Tacitus describes is not something that can be seen in the official version of the meaning of the trial, for there the Senate limited itself to giving thanks for the fact that Piso's civil war had not succeeded in disrupting the status quo. But it is no surprise that there should also be a gap between the official version of history and history itself. 
quaeque ambigua sunt (3.19.2) —we have seen that by telling the story twice he has in fact given his readers a powerfully coherent (though not necessarily correct) interpretation of an episode that he himself presents as one of the most important developments of Tiberius' reign.

In connection with Agrippa Postumus' death, "the first crime of the new reign" (1.6.1), a sagacious advisor warns Tiberius that "a condition of autocratic rule is that the accounts will not balance unless the ruler is their only auditor" (eam condicionem esse imperandi, ut non aliter ratio constet quam si uni reddatur, 1.6.3). In this case Tiberius takes the implied advice and resists his inclination to involve the Senate. The incident quickly faded from view. Deaths in the imperial family, it seems, are the inevitable concomitant of dynasty, as Tacitus' numerous Parthian and Armenian narratives show. When Germanicus dies, however, Tiberius submits the accounts to the Senate, with the populace watching agog. That the accounts do not balance, that the truth as Tacitus had established it in his narrative could not possibly emerge in this forum, and that a surplus of suspicion remains after all is settled, is a condition of the autocratic essence of Augustus' restored republic. ${ }^{27}$

AmHerst College

e-mail: cdamon@amherst.edu

\section{BIBLIOGRAPHY}

De Jong, I. J. F. 1985. “Iliad I.366-392: A Mirror Story.” Arethusa 18:5-22. 1987. Narrators and Focalizers: The Presentation of the Story in the Iliad. Amsterdam: B. R. Grüner.

Develin, R. 1983. "Tacitus and Techniques of Insidious Suggestion." Antichthon 17:64-95.

Eck, W., A. Caballos, and F. Fernández. 1996. Das Senatus Consultum de Cn. Pisone Patre. Vestigia 48. Munich: C. H. Beck.

Gomme, A. W. 1956. A Historical Commentary on Thucydides. Vol. II, Books II-III. Oxford: Clarendon Press.

${ }^{27}$ This essay has benefited from the suggestions and criticisms of many people, whom I thank again here: E. Badian, J. Bodel, C. P. Jones, C. Mackay, S. Myers, J. B. Rives, $\mathrm{S}$. Treggiari, and this Journal's editor, P. Stadter. An earlier version was presented to the New England Ancient Historians Colloquium, where the discussion was, as always, both lively and helpful. Errors and inadequacies in the present version are my own. 
Goodyear, F. R. D., ed. 1981. The Annals of Tacitus, Books 1-6. Vol. II, Annals 1.55-81 and Annals 2. Cambridge: Cambridge University Press.

Hornblower, S. 1991. A Commentary on Thucydides. Vol. I, Books 1-3. Oxford: Clarendon Press.

Martin, R. H., and A. J. Woodman, eds. 1989. Tacitus: Annals Book 4. Cambridge: Cambridge University Press.

Paladini, M. L. 1984. "A proposito del parallelo Alessandro Magno-Germanico Cesare in Tacito." In Alessandro Magno tra storia e mito, edited by M. Sordi, 179-93. Milan: Jaca Books.

Talbert, R. J. A. 1984. The Senate of Imperial Rome. Princeton: Princeton University Press.

Walker, B., ed. 1952. The Annals of Tacitus. Manchester: Manchester University Press.

Woodman, A. J., and R. H. Martin, eds. 1996. The Annals of Tacitus, Book 3. Cambridge: Cambridge University Press. 